\title{
How Lipid-Specific T Cells Become Effectors: The Differentiation of iNKT Subsets
}

\author{
Haiguang Wang and Kristin A. Hogquist* \\ Department of Laboratory Medicine and Pathology, Center for Immunology, University of Minnesota, Minneapolis, MN, \\ United States
}

In contrast to peptide-recognizing $T$ cells, invariant natural killer $\mathrm{T}$ (iNKT) cells express a semi-invariant $T$ cell receptor that specifically recognizes self- or foreign-lipids presented by CD1d molecules. There are three major functionally distinct effector states for iNKT cells. Owning to these innate-like effector states, iNKT cells have been implicated in early protective immunity against pathogens. Yet, growing evidence suggests that iNKT cells play a role in tissue homeostasis as well. In this review, we discuss current

OPEN ACCESS

Edited by:

Luc Van Kaer,

Vanderbilt University,

United States

Reviewed by:

Paolo Dellabona,

San Raffaele Scientific Institute

(IRCCS), Italy

Sebastian Joyce,

Vanderbilt University,

United States

${ }^{*}$ Correspondence:

Kristin A. Hogquist

hogqu001@umn.edu

Specialty section:

This article was submitted

to T Cell Biology,

a section of the journal

Frontiers in Immunology

Received: 01 May 2018

Accepted: 12 June 2018

Published: 26 June 2018

Citation:

Wang $H$ and Hogquist KA (2018)

How Lipid-Specific T Cells

Become Effectors: The

Differentiation of iNKT Subsets.

Front. Immunol. 9:1450.

doi: 10.3389/fimmu.2018.01450 knowledge about the underlying mechanisms that regulate the effector states of iNKT subsets, with a highlight on the roles of a variety of transcription factors and describe how each subset influences different facets of thymus homeostasis.

Keywords: invariant natural killer T cell, subsets, development, lipid, thymus, mucosal-associated invariant T cell

\section{INTRODUCTION}

Natural killer T cells (NKT) were named because they express $\mathrm{T}$ cell receptor (TCR)-CD3 complexes as well as the natural killer (NK) cell receptor NK1.1 (CD161) (1,2). Later, research discovered that NKT cells express a semi-invariant TCR, characterized by a V $\alpha 14-J \alpha 18$ TCR $\alpha$ chain coupled with a limited $\mathrm{V} \beta$ repertoire $(\mathrm{V} \beta 2, \mathrm{~V} \beta 7$, or $\mathrm{V} \beta 8.2)$ in mice, and an invariant $\mathrm{V} \alpha 24-\mathrm{J} \alpha 18$ paired with $\mathrm{V} \beta 11$ in humans $(3,4)$. Owning to this semi-invariant TCR, invariant natural killer T (iNKT) cells recognize self- and foreign-lipid antigens presented by the CD1d molecule and could be specifically detected using CD1d tetramer loaded with a cognate lipid antigen.

iNKT cells originate in the thymus, but in contrast to the conventional peptide specific $\mathrm{CD}^{+}$or $\mathrm{CD}^{+} \mathrm{T}$ cells, which are positively selected by cortical thymic epithelial cells, the positive selection of iNKT cells solely relies on the interactions among cortical double-positive (DP) thymocytes (5-7). DP thymocytes expressing the rearranged Vo14-J 18 TCR recognize high-affinity lipid antigens presented by CD1d molecules on neighboring DP thymocytes (4). iNKT cells highly express the transcription factor promyelocytic leukemia zinc finger protein PLZF $(z b t b 46)$, which is essential for their effector program $(8,9)$, for specifying the tissueresident properties of iNKT cells, and for their ability to produce cytokines early after stimulation $(8-10)$.

It has been realized that iNKT cells are a heterogenous population, and recent evidence from various groups suggest that there are three major functional iNKT subsets at steady state according to their expression of lineage-specific transcription factors and cytokine-producing potential. The three iNKT subsets are designated NKT1, NKT2, and NKT17, in analogy to the classical CD4 T helper lineages. NKT1 cells are PLZF low T-bet ${ }^{+}$and produce both IFN- $\gamma$ and low amounts of IL-4 after stimulation. They express NK1.1 and other NK receptors and represent the subset that "NKT" 
cells were named after. NKT2 and NKT17 cells, in contrast, do not express NK1.1. NKT2 cells are PLZF ${ }^{\text {high }}$ and produce high amounts of IL- 4 at steady state and after stimulation. NKT17 cells are PLZF ${ }^{\text {intermediate }}$ ROR- $\gamma \mathrm{t}^{+}$and produce IL-17 after stimulation (11). Through intra-thymic transfer and fetal thymic organ culture (FTOC), previous studies demonstrated that each iNKT subset (NKT1, NKT2, and NKT17) is terminally differentiated; i.e., do not give rise to other cell subsets (11-13). iNKT cells play diverse roles in immunity due in part to the existence of these three functional subsets. The subsets produce distinct cytokines and reside in distinct tissues. With accumulating knowledge regarding the biology of iNKT cells, in this review, we summarize recent advances in the development and differentiation of iNKT subsets, as well as their role in maintaining the immune homeostasis.

\section{THE DEVELOPMENT AND DIFFERENTIATION OF iNKT CELLS}

\section{Initial Positive Selection}

Like the conventional $\mathrm{CD}^{+}$and $\mathrm{CD}^{+} \mathrm{T}$ cells, iNKT cells originate from precursors undergoing TCR gene rearrangement in the thymus. A lineage tracing study using transgenic mice (ROR$\left.\gamma \mathrm{t}-\mathrm{Cre} \times \mathrm{ROSA} 26^{\mathrm{lsl}}-\mathrm{EGFP}\right)$ in which ROR- $\gamma$ t triggers permanent expression of green fluorescent protein (GFP) confirmed that iNKT cells were derived from ROR- $\gamma \mathrm{t}^{+} \mathrm{DP}$ thymocytes in the thymus (5) (Figure 1 "Selection"), while a minor population could arise from DN thymocytes bypassing DP stage (14). Moreover, ROR- $\gamma \mathrm{t}$ itself is essential for iNKT cell generation, in that, it supports DP survival through regulating $\mathrm{Bcl}-\mathrm{xL}$ expression, allowing for optimal rearrangement of V $\alpha 14-J \alpha 18$ TCR chains

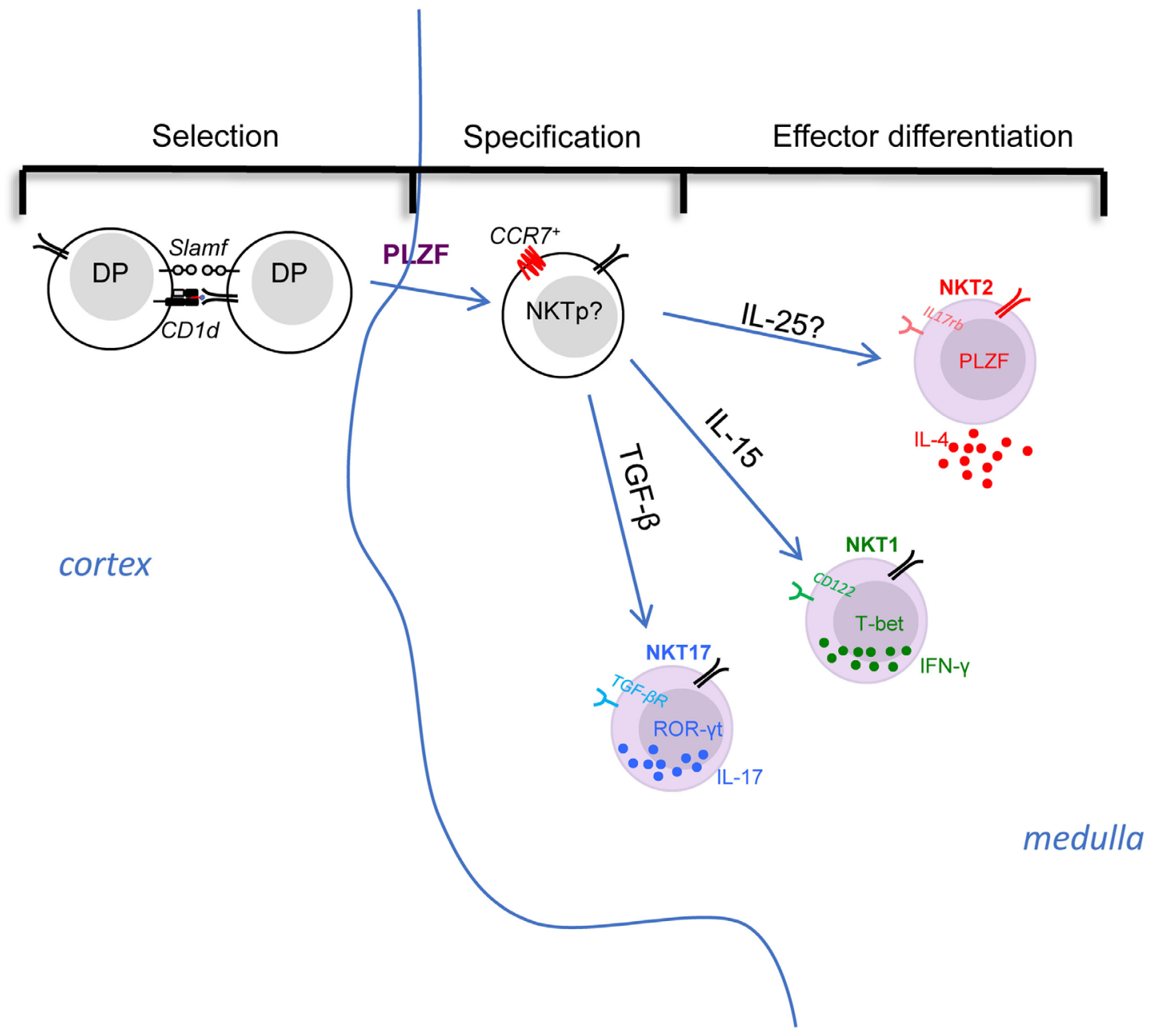

FIGURE 1 | The selection, specification, and effector differentiation of invariant natural killer T (iNKT) cells in the thymus. The initial positive selection of iNKT cells depends on the interaction among double-positive thymocytes in cortex. Then, with the upregulation of PLZF and the chemokine receptor CCR7, the multi-potent iNKT common precursors migrate to thymic medulla and specify their fate into different effector subsets. The effector differentiation into NKT1, NKT2, and NKT17 are influenced and directed by various factors. For instance, cytokine signals play essential roles in differentiation: IL-15 is critical for CD122 expressing NKT1 cell differentiation, whereas TGF- $\beta$ is required for TGF- $\beta$ R-expressing NKT17 cells, while NKT2 cells express IL-17 RB (IL-25 receptor), although the role of IL-25 requires evaluation. iNKT subsets are poised in an effector state, but only NKT2 cells are actively producing cytokine (IL-4) at steady state, while NKT1 and NKT17 cells maintain potential to produce IFN- $\gamma$ or IL-17, respectively, after stimulation. 
(15). Similarly, an E protein transcription factor, HEB, promotes survival of DP thymocytes through regulating both ROR- $\gamma \mathrm{t}$ and $\mathrm{Bcl}-\mathrm{xL}$ expression, which opens the window of time to allow distal J $\alpha$ rearrangement (16). Downstream of the initial selection of DP thymocytes, c-Myc has been shown to control the maturation of iNKT cells $(17,18)$. Moreover, c-Myb has also been shown to play a central role in this process, as it supports long half-life of DP thymocytes to allow V $\alpha 14$ to J $\alpha$ rearrangement (19).

Immediate post-selection precursor iNKT cells are characterized as CD1d tetramer ${ }^{+} \mathrm{CD} 44^{-} \mathrm{CD} 24^{+} \mathrm{CD} 69^{+}$, termed as "stage 0" iNKT cells. The strong TCR signal during iNKT selection was directly demonstrated using a reporter mouse in which a GFP cassette was inserted in the Nur77 locus (an immediate-early gene upregulated by TCR stimulation), wherein the GFP level indicates the TCR signal strength (20). In these mice, stage 0 iNKT cells express a high level of GFP indicating they received strong TCR signal during selection (20). Beside this strong TCR signal, the development of iNKT cells also relies on a "second signal" generated through homotypic interactions between signaling lymphocyte activation molecule family (SLAMF) receptors, SLAMF1 and SLAMF2, expressed on the DP thymocytes (21). In addition to supporting a long half-life in DP thymocytes, c-Myb also promotes the expression of CD1d and SLAMFs, which are essential for positive selection of iNKT cells (19). Deficiency of c-Myb completely abrogates the generation of iNKT cells, as $\mathrm{CD} 24^{+}$stage 0 iNKT cells were NOT detected (19).

Historically, in $\mathrm{B} 6$ mice, the maturation of iNKT cells beyond stage 0 was described as a stepwise linear model from stage 1 to 3 based on expression of CD44 and NK1.1. In this model, the stage 0 iNKT cells develop into CD24- $\mathrm{CD} 44^{-} \mathrm{NK} 1.1^{-}$stage 1 cells, then upregulate CD44 to become stage 2 cells, and finally acquire NK1.1 expression to become stage 3 cells in a linear fashion (22). This model fits some but not all the available data. For example, NKT17 cells were known to express CD44 but not NK1.1 (stage 2), never become NK1.1+ (stage 3) (12). Alternatively, based on the expression of transcription factors, PLZF, Gata3, T-bet, and ROR- $\gamma$ t, CD24- iNKT cells could be very well categorized into three distinct subsets, NKT1, NKT2, and NKT17 as described above. Similar to NKT17 cells, intrathymic transfer of "stage 2" IL-4 producing NKT2 cells (IL- $4^{+}$ IL-17RB ${ }^{+} \mathrm{CD}^{+}$) showed that they do not give rise to T-bet ${ }^{+}$ NK1.1 + "stage 3" cells either (11). Therefore, a revised lineagediversification model for iNKT cell development, in which a common progenitor gives rise to the distinct lineages of NKT1, NKT2, and NKT17 cells (Figure 1) was suggested. We herein discuss the promoting and inhibitory factors for selection, specification, and differentiation of iNKT cells, which are summarized in Table 1.

\section{Specification}

Stage 0 iNKT cells arise from DP thymocytes in the thymic cortex (6). However, in CD1d tetramer-based immunofluorescence and histocytometric analysis, thymic iNKT subsets were found to be predominantly localized in the thymic medulla (23) (Figure 1). Consistent with this, the thymic medullary environment was reported to impact the functional maturation of iNKT cells (24). Therefore, the nature and localization of the common progenitor that directly gives rise to distinct subsets is unclear. Furthermore, the signals that drive their migration from cortex to medulla, as well as the medullary factors that control the differentiation of iNKT subsets has not yet been reported. A previous study demonstrated that the chemokine receptor CCR7, which responds to the chemokines CCL21, is important for thymocytes trafficking from the cortex to the medulla (25). Additionally, the number of iNKT cells was significantly reduced in CCR7 $7^{-/-}$mice (26). Interestingly, single cell RNA-seq analysis of thymic iNKT cells suggested that PLZFigh iNKT cells might comprise a progenitor population (27). Previous work showed IL- $4^{-}$PLZF ${ }^{\text {high }}$ iNKT cells could further differentiate into T-bet ${ }^{+}$NKT1 cells when sorted and intra-thymically transferred into thymus (11), suggesting they maintain precursor potential. Further analysis of this IL-4 PLZF $^{\text {hi }}$ iNKT cell population by RNA-seq and PCA analysis confirmed they have the least similarity to the three effector subset (28). Taken together, it could be inferred that CCR7 ${ }^{+}$cells within

TABLE 1 | Genetic factors influence development of iNKT subsets.

\begin{tabular}{|c|c|c|c|c|c|}
\hline \multirow[t]{10}{*}{ Promoting factors } & \multirow[t]{2}{*}{ Selection } & \multirow[t]{2}{*}{ Specification } & \multicolumn{3}{|c|}{ Effector differentiation } \\
\hline & & & NKT1 & NKT2 & NKT17 \\
\hline & $\mathrm{ROR}-\gamma \mathrm{t}$ & PLZF & CD122/IL-15 & IL-17RB/IL-25? & TGF- $\beta$ RII/TGF- $\beta$ \\
\hline & HEB & Runx1 & Let-7 & \multicolumn{2}{|c|}{ Lin28 } \\
\hline & C-Myc & CUL3 & \multicolumn{2}{|c|}{ Pak2 } & \\
\hline & C-Myb & CCR7/CCL21a & Hobit & $\begin{array}{l}\text { T cell receptor (TCR) } \\
\text { binding half-life }\end{array}$ & \\
\hline & SLAMF1 and SLAMF2 & Egr2 & UTX & KLF13 & \\
\hline & miR-181a & NKAP & \multicolumn{2}{|c|}{ T cell factor 1} & \\
\hline & TCR signaling strength & Histone deacetylase 3 & \multicolumn{3}{|c|}{ Lymphoid enhancer factor 1 (preferentially promote NKT2) } \\
\hline & & Dicer/microRNAs & & & \\
\hline \multirow[t]{4}{*}{ Inhibitory factors } & & & Lin28 & \multicolumn{2}{|c|}{ Let-7 } \\
\hline & & & TCR binding half-life & Kruppel-like factor 2 & TET2/TET3 \\
\hline & & & \multicolumn{3}{|c|}{ Jarid2 } \\
\hline & & & & Ezh2 & \\
\hline
\end{tabular}


PLZF ${ }^{\text {high }}$ iNKT cells might serve as the common progenitor for iNKT subsets (Figure 1 "Specification”).

\section{Factors Involved in Specification and/or Effector Differentiation Cytokines}

\section{IL-15, TGF- $\beta$, and IL-25}

Numerous studies have demonstrated cytokines produced in the local environment play central roles in determining the differentiation of CD4 ${ }^{+} \mathrm{T}$ helper subsets (Th1, Th2, and Th17) (29). Similarly, the differentiation of iNKT subsets is heavily influenced by different cytokine signals (Figure 1 "Effector differentiation"). For instance, it's been shown that NKT1 cells highly express CD122 (IL2R $\beta$ ), and CD122-mediated IL-15 signaling is essential for the differentiation of NKT1 cells (30). Likewise, the absence of TGF- $\beta$ signaling (CD4-Cre $\times$ TGF- $\beta$ RII flox/flox $^{\text {and CD } 4-C r e ~} \times$ Smad $44^{\text {flox/flox }}$ ) led to complete loss of ROR- $\mathrm{t}^{+}$NKT17 cells (31). Both NKT2 and NKT17 cells express IL-17RB (IL-25 receptor), which was essential for the production of IL-13, IL-9, IL-10, and IL-17 after stimulation with $\alpha \mathrm{GalCer}$ (13), demonstrating that the cytokine production of activated iNKT cells is influenced by a signal through this receptor. It was further shown that such effect was dependent on $\mathrm{E} 4 \mathrm{BP} 4$, a transcription factor that regulates IL-10 and IL-13 production in CD4 ${ }^{+} \mathrm{T}$ and iNKT cells $(32,33)$. Interestingly, E4BP4 seems to be upregulated in iNKT cells only after stimulation with IL-25 or $\alpha$ GalCer $(13,33)$, but not expressed by thymic or most peripheral iNKT cells in the steady state (except the adipose iNKT cells) $(13,33,34)$. Though inferred by the data, iNKT subsets defined by transcription factor expression as NKT1, 2, and 17 were not directly evaluated in the study (13). Thus, whether the development of NKT2 and/or NKT17 cells is controlled by the IL-17RB/IL-25 axis remains or be defined. In a scenario where IL-25 signaling controls differentiation of NKT cells, it would be important to define the source of IL-25 in the thymus (Figure 1; Table 1). A recent study demonstrated that a type of specialized epithelial cells, called tuft cells, are the solely source of IL-25 in the gut (35). It will be interesting to check the thymus for this lineage of epithelial cells as well.

\section{Transcription Factors \\ Egr2}

Strong TCR signaling in stage 0 iNKT cells commits their fate to iNKT lineage, as it leads to elevated expression of the transcription factors Egr1 and Egr2, which influence further development of iNKT cells (36). In agreement with Egr2 directly binding the PLZF promoter, Egr1 and Egr2 together are critical for PLZF induction, which indicates that Egr1 and Egr2 may be upstream of PLZF in determining iNKT lineage fate (36). In addition, Egr2-deficient iNKT cells failed to express CD122, indicating that elevated Egr2 expression not only specifies iNKT lineage at an early stage but its sustained expression may also further influence differentiation of iNKT subsets (36). In addition, a cytoskeletal remodeling protein, P21-activated kinase 2 (Pak2) also influences the development of iNKT cells, especially NKT1 and NKT2 cells, possibly through regulation of the two critical transcription factors, Egr2 and PLZF (37).

\section{KLF Family Factors}

The transcription factor Kruppel-like factor 2 (KLF2) is essential for T cells egress from thymus and lymph node, because it's required for the expression of sphingosine 1 phosphate receptor type 1 (S1P1) in T cells (38). Unexpectedly, thymocytes in KLF2deficient mice (CD4-Cre $\times \mathrm{KLF}^{\text {flox/flox }}$ ) displayed a memory phenotype $\left(\mathrm{CD} 44^{\text {high }} \mathrm{CXCR}^{+} \mathrm{CD} 122^{+}\right)$that was shown to be an IL-4-dependent cell-nonautonomous effect (39). Furthermore, this effect was due to the expansion of IL-4-producing PLZF ${ }^{\text {high }}$ T cells (mostly NKT2 cells), showing that KLF2 negatively regulates the differentiation of NKT2 cells (40). Another member of the Kruppel-like family, KLF13, plays the opposite role. KLF13 deficiency $\left(\mathrm{KLF}^{-/} 3^{--}\right)$led to a diminished population of IL-4producing PLZF ${ }^{\text {high }}$ iNKT cells (41).

\section{Hobit}

Though serving as an important factor that instructs the tissue retention program in iNKT cells and resident memory $\mathrm{T}$ cells (Trm) (42), the transcription factor Hobit was also shown to regulate the differentiation of iNKT cells (43). Hobit expression is high in CD44 ${ }^{\text {high }}$ NK1.1 $1^{+}$iNKT cells (mostly NKT1 cells), but low in CD44 ${ }^{\text {low }} \mathrm{NK} 1.1^{-}$and CD $44^{\text {high }} \mathrm{NK} 1.1^{-}$iNKT cells (mostly NKT17 and NKT2 cells) (43). Accordingly, the number of CD $44^{\text {high }} \mathrm{NK} 1.1^{+}$iNKT cells was significantly reduced in Hobitdeficient mice, while the abundance of CD $44^{\text {low }} \mathrm{NK} 1.1^{-}$and CD44 ${ }^{\text {high }}$ NK1.1- ${ }^{-}$iNKT cells remained intact (43). Though the iNKT subsets were not distinguished in the study, it could be inferred from the data that Hobit promotes the differentiation and/or thymic retention of NKT1 cells.

\section{Lymphoid Enhancer Factor 1 (LEF1) and T Cell Factor 1 (TCF1)}

The transcription factors LEF1 and TCF1 are essential for T cell development including early commitment to the $\mathrm{T}$ cell fate, transition from DN to the DP thymocytes, as well as following CD4/CD8 choice (44). The critical role of LEF1 and TCF1 in the differentiation of iNKT subsets has also been shown. Deletion of TCF1 at DP stage (CD4-Cre $\times$ Tcf $7^{\text {flox/flox }}$ ) led to a severe defect in all three iNKT subsets (45). In addition, iNKT cell development was similarly impaired in absence of LEF1 (Vav-Cre $\times$ Lef $1^{\text {flox/flox }}$ ) (46). LEF1 was required for the proliferation and survival of iNKT cells, especially the massive expansion after stage 0 (46). Interestingly, though it influenced the development of all three iNKT subsets, LEF1 showed a preference in promoting the differentiation of NKT2 cells (46).

\section{Chromatin Modifiers}

Epigenetic modifications also regulate development and differentiation of iNKT cells. The TET-family dioxygenases, TET1, TET2, and TET3, oxidize 5-methylcytosine $(5 \mathrm{mC})$ to 5-hydroxymethylcytosine $(5 \mathrm{hmC})$, which is an important DNA modification critical for various biological processes (47-49). Simultaneous deletion of Tet 2 and Tet 3 resulted in uncontrolled TCR-mediated expansion of NKT17 cells through suppression of T-bet and ThPOK (50). Jarid2, a component of polycomb repressive complex 2 that methylates histone 3 lysine 27 (H3K27), is also involved in iNKT cells development. Upregulated after TCR stimulation, Jarid2 directly binds to the PLZF promotor as a transcriptional 
repressor. Therefore, deficiency of Jarid2 led to significant expansion of PLZF ${ }^{\text {high }}$ NKT2 cells (51). In addition, the transcriptional repressor NKAP was shown to be required for the development of iNKT cells, as the iNKT development was completely abrogated at stage 0 in mice deficient of NKAP (CD4-Cre $\times$ NKAP flox/flox) (52). How NKAP regulates iNKT cell development is not clear, but its interaction with the histone deacetylase 3 (Hdac3) may be important, as NKAP is known to associate with Hdac3 and a similar defect of iNKT cells was observed in Hdac 3 conditional knockout mice $\left(\mathrm{CD} 4-\mathrm{Cre} \times \mathrm{Hdac} 3^{\text {flox/flox }}\right.$ ) (53). A recent report demonstrated that the $\mathrm{H} 3 \mathrm{~K} 27 \mathrm{me} 3$ histone demethylase UTX is essential for iNKT cell development, especially the differentiation of NKT1 cells, as there was considerably fewer T-bet ${ }^{+} \mathrm{NKT} 1$ cells in UTX-deficient mice while NKT2 and NKT17 cells were not affected (54). UTX not only directly binds to the promoters of T-bet and CD122 genes but also influences the epigenetic landscape and transcription of PLZF-activated genes (54).

\section{MicroRNAs (miRNAs)}

MicroRNAs are small noncoding single-strand RNAs ( 22 nt) that modulate the stability and transcriptional activities of messenger RNAs (mRNAs) and via this mechanism influence the transcriptomes of various cells, leading to further effects on cellular proliferation, apoptosis, lineage commitment, and differentiation (55). Perhaps not surprisingly, complete loss of mature iNKT cells was observed in mice lacking Dicer (CD4Cre $\times$ Dicer $\left.^{\text {flox/flox }}\right)$, which are incapable of generating functional miRNAs in T cells, thus demonstrating that miRNAs are essential for the development of iNKT cells (56). miR-181a is abundant in DP thymocytes and could augment TCR signaling strength via enhancing the basal activation of TCR signaling molecules, such as increased basal phosphorylation level of Lck and ERK (57). Deletion of miR-181a (miR-181a/b-1 $1^{-/-}$mice) completely blocked iNKT cell development at the DP/Stage 0 , which was presumably due to reduced responsiveness to TCR signals as exogenous agonistic ligand ( $\alpha \mathrm{GalCer})$ could rescue iNKT cell generation (58). The miR-17-92 family cluster is also critical for the development of iNKT cells, in that absence of miRNAs of the miR-17-92 family cluster (triple knockout of three paralogs miR-17-92, miR-106a-363, and miR-106b-25 clusters) resulted in almost complete ablation of the three iNKT effector subsets (59). Excessive TGF- $\beta$ signaling was seen in the remaining triple knockout iNKT cells, but it did not solely account for the impaired iNKT cell development, because deletion of TGF- $\beta$ RII did not fully restore the hemostasis of iNKT cells (59). It was further found that the Let-7 family miRNAs, the most abundant family of miRNAs in mammals, tightly controls the differentiation of iNKT subsets $(60,61)$. Let-7 miRNAs are abundant in NKT1 cells while low in NKT2 and NKT17 cells, targeting Zbtb46 mRNAs and inhibiting PLZF expression, therefore, directing iNKT cell differentiation into PLZF ${ }^{\text {low }}$ NKT1 lineage (61). Moreover, Lin28 inversely regulates Let-7 miRNAs, and Lin28 transgenic mice, which are practically deficient in Let-7 miRNAs, showed significantly increased NKT2 and NKT17 cells (61). miR-150 is expressed in lymphocytes (B, T, and NK cells) and has been implicated in their maturation. Correspondingly, miR150 expression is expressed in iNKT cells after stage $0(62,63)$.
In a mixed bone marrow chimera system, cell-intrinsic deficiency of miR-150 mildly affected iNKT cell development $(62,63)$, while overexpression of miR-150 substantially blocked maturation of iNKT cells beyond stage 0 (62). This suggests that fine-tuning of miR-150 level might be critical for iNKT cell development. Though the molecular pathway underlying this miR-150-dependent iNKT cell development is unclear, regulation of c-Myb by miR-150 could be involved $(62,63)$.

\section{Cellular Protein Degradation System}

While playing a central role in iNKT cell development, PLZF is initially induced in the stage 0 iNKT cells, and its expression can be regulated by the transcription factor Runx1 through direct binding to a critical enhancer of PLZF gene (64). Using Chip-Seq analysis, PLZF was shown to bind and regulate multiple genes, especially a broad set of immune effector genes expressed in iNKT cells (65). Beside directly regulating the expression of various genes, PLZF was also shown to transport an E3 ubiquitin ligase, cullin 3 (CUL3), from cytosol to nucleus, which would induce unique and essential ubiquitination patterns in iNKT cells (66). The number of iNKT cells was dramatically decreased in mice lacking CUL3 $\left(\mathrm{CD} 4-\mathrm{Cre} \times \mathrm{CUL}^{\text {flox/flox }}\right.$ ), further substantiating the importance of PLZF-CUL3 interaction in the development of iNKT cells (66). In line with its association with CUL3, PLZF has also been reported to interact with enhancer of zeste homolog 2 (Ezh2) methyltransferase (67). Moreover, Ezh2 directly methylates PLZF, causing its ubiquitination and subsequent degradation. Deletion of Ezh2 leads to sustained expression of PLZF and substantial expansion of PLZFigh NK1.1- iNKT cells (mostly IL-4-producing NKT2 cells) (67).

\section{Endogenous Selecting Lipid-Ligand and TCR Specificity}

The generation of iNKT cells depends on recognition of lipid antigen presented by CD1d molecules on DP thymocytes. This antigen is most likely to be a self-lipid(s), because iNKT cells emerge early in life $(6,68)$, before stable colonization of commensal bacterial. Moreover, the phenotype and function of thymic and most peripheral iNKT cells (except pulmonary and intestinal iNKT cells) are normal in germ-free mice $(69,70)$. Regulated lipid metabolism in DP thymocytes is critical for thymic selection of iNKT cells, and the transcription factor Bcl11b plays a vital role in this process (71). Bcl11b-deficient (CD4-Cre $\times$ Bcl11 $b^{\text {flox/flox }}$ ) thymocytes showed deficient presentation of endogenous lipid antigens, dysregulated endo-lysosomal compartment, and alterations in genes involved in lipid metabolism (71). Moreover, in a mixed bone marrow chimera system, Bcl11b-deficient DP thymocytes (TCR- $\alpha^{-/-} / \mathrm{CD} 4-\mathrm{Cre} \times \mathrm{Bcl} 11 \mathrm{~b}^{\text {flox/flox}}$ ) failed to support selection of iNKT precursors in Bcl11b-sufficient DP thymocytes $\left(\beta 2 \mathrm{~m}^{-1-} / \mathrm{Bcll1} 1 \mathrm{~b}-\mathrm{Wt}\right)$ (71). CD1d molecules can traffic between cell membrane and cytosolic organelles, surveying the endolysosomal compartment (72). A mouse model that expresses CD1d with a truncated cytoplasmic tail showed a severe defect in intracellular trafficking, and the number of iNKT cells was significantly reduced, suggesting the selection of iNKT cells relies on endosomal trafficking of CD1d molecule (73). 
Though a great effort has been made to understand the stimulatory thymic self lipid(s), controversy remains, as reviewed elsewhere $(22,74,75)$. Briefly, iGb3, an endogenous lysosomal glycosphingolipid, though thought to be presented by LPS-activated dendritic cells that activate iNKT cells (76), is unlikely to be a major selecting ligand for iNKT cells given that the development and function of iNKT cells are normal in isoglobotrihexosylceramide (iGb3)-deficient mice (77). Instead, glycosphingolipids (GSL) have been implicated in the development of iNKT cells as mice deficient of GSL-synthesizing enzyme glucosylceramide (GlcCer) synthase (GSC) in hematopoietic cells (Vav-Cre $\times \mathrm{GCS}^{\text {flox/flox }}$ ) showed mild reduction of iNKT cells in both thymus and periphery (78). While stage 0 iNKT cells were not examined in the study, it remains unclear whether GSL are involved in the positive selection of iNKT cells. A recent report demonstrated the selecting ligands likely to be $\alpha$-linked glycosylceramides (79). Since all glycosylceramides in mammals were believed to be $\beta$-anomers due to that mammalian glycosylceramide synthases are $\beta$-transferases (80), this finding is somewhat surprising. Earlier studies pioneered by the Brenner group showed, though initially thought to be a potent lipid self-antigen for iNKT cells, that $\beta$-glucopyranosylceramide $(\beta$-GlcCer) actually does NOT possess antigenic activity to iNKT cells $(81,82)$. The observed activity of $\beta$-GlcCer is likely due to inclusion of an $\alpha$-GlcCer species (82). These observations suggested the possibility that $\alpha$-glycolipids are endogenous antigenic lipids for iNKT cells (82). However, nuclear magnetic resonance spectroscopy analysis at the time did not render a definitive identity (82). It is possible that an unknown alternative enzymatic pathway, unfaithful enzymatic activities, or unique stressed cellular environments could confer production of small amounts of $\alpha$-linked glycolipids, though the exact mechanism remain to be discovered $(79,83)$. The peroxisome-derived ether lipids seem to be partially involved in the iNKT cell development, as mice deficient in the peroxisomal enzyme glyceronephosphate O-acyltransferase (GNPAT) harbor moderately reduced iNKT cells and $\mathrm{GNPAT}^{-1-}$ thymocytes are unable to support maturation of iNKT cells (84). However, the number of stage 0 iNKT cells are NOT changed in $\mathrm{GNPAT}^{-/-}$ mice (84), suggesting that peroxisome-derived lipids may not be the predominant selecting ligands for iNKT cells, but rather influence later developmental events of iNKT cells. The lysosomal phospholipase A2 (LPLA2), which modifies lysophospholipids in the lysosome, has been shown to play a role in thymic selection of iNKT cells, as both CD1d endogenous antigen presentation and iNKT cell numbers were negatively affected in the absence of LPLA2 (85). Taken together, considering that maturation of iNKT cells after positive selection of stage 0 iNKT cells requires the presence of CD1d in the thymus (86), it is possible that the endogenous lipid ligands for iNKT cells are presented in both thymic cortex and medulla and are displayed by different antigenpresenting cells (APCs). In this fashion, they may influence both selection (in the cortex) and effector differentiation (in the medulla) of iNKT cells (Figure 2).

Consistent with a potential role of specific self-lipids in effector differentiation, it was noted that the three iNKT subsets express distinct but stable $\mathrm{V} \beta$ repertoires $(11,87,88)$. For example, NKT2 cells show a higher usage of V $\beta 7$ (11). Thus, a few studies have raised the hypothesis that differential TCR signaling events due to biased TCR V $\beta$ gene usage could impact the differentiation of iNKT subsets $(87,88)$. Through generation of retrogenic mice expressing different CDR3 $\beta$ to manipulate iNKT TCR $\beta$ chain in vivo, a recent study clearly demonstrated the half-life of TCR-Ag-CD1d interaction governs the frequency of different iNKT subsets in a cell-intrinsic manner. The number of NKT2 cells strongly correlated with the $t_{1 / 2}$ of tetramer binding (89). As mentioned above, a high level of Nur77GFP was seen in NKT2 cells in the steady state, suggesting continuous TCR signaling in NKT2 cells (11). However, it is less clear whether such continuous TCR stimulation is required for the steady-state production of IL-4 in NKT2 cells and/or the development of PLZF ${ }^{\text {high }}$ NKT2 cells (Figure 2). Since NKT2 cells reside in the thymic medulla, further efforts are required to elucidate where and how TCR binding kinetics of NKT2 cells might control their differentiation (Figure 2).

\section{INKT CELLS MODULATE TISSUE HOMEOSTASIS}

\section{Major Role of iNKT-Derived IL-4 Thymus}

Using KN2 mice, in which a human CD2 cassette was knocked into the IL-4 gene locus, and human CD2 expression on cell surface indicates active secretion of IL-4, a previous study demonstrated that thymic NKT2 cells produce abundant IL-4 at steady state (11). Another group showed thymic iNKT cells may also produce IL-13 at steady state in IL-13GFP mice (90). Because iNKT cells are predominantly localized in the medulla, IL-4 produced by NKT2 cells could influence a variety of immune events in that environment (Figure 2). Indeed, steady-state production of IL-4 selectively activates STAT6 in medullary $\mathrm{CD}^{+}$single-positive thymocytes, which drives them to become memory phenotype $\left(\mathrm{CXCR}^{+}{ }^{+} \mathrm{CD}_{122}{ }^{+}\right.$Eomes $\left.^{+}\right)(11,40)$. This population of IL-4induced memory $\mathrm{T}$ cells has been categorized as innate memory $\mathrm{T}$ cells (91), and they maintain greater function compared to naive $\mathrm{CD}^{+} \mathrm{T}$ cells. They are well equipped to produce IFN- $\gamma$ in response to TCR stimulation and showed much better expansion after infection with listeria monocytes (LM) (40). Moreover, the developmental exposure to $\mathrm{IL}^{-4}$ is critical for $\mathrm{CD}^{+} \mathrm{T}$ cells to mount robust Th1 responses to acute or chronic lymphocytic choriomeningitis virus infection $(92,93)$. Therefore, innate memory $\mathrm{T}$ cells are beneficial to the host for their functional superiority (94). Nevertheless, we do not yet understand, in the bigger picture, why iNKT cells recognition of medullary selflipids should control this process.

IL-4 impacts other immune cells beyond CD8 T cells in thymic medulla. A recent study demonstrated that the type 2 cytokines (IL-4/13) produced by iNKT cells could influence in the thymic emigration of mature thymocytes (90). IL-4R $\alpha^{-/-}$mice showed accumulation of mature $\mathrm{T}$ cell in the thymus and reduced recent thymic emigrants in the periphery (90). Medullary thymic epithelial (mTEC) cells express IL-4R $\alpha$ and can respond to the type 2 cytokines, as pSTAT6 level went up in mTEC of FTOC when IL-4 and IL-13 were added in the culture (90). Moreover, 


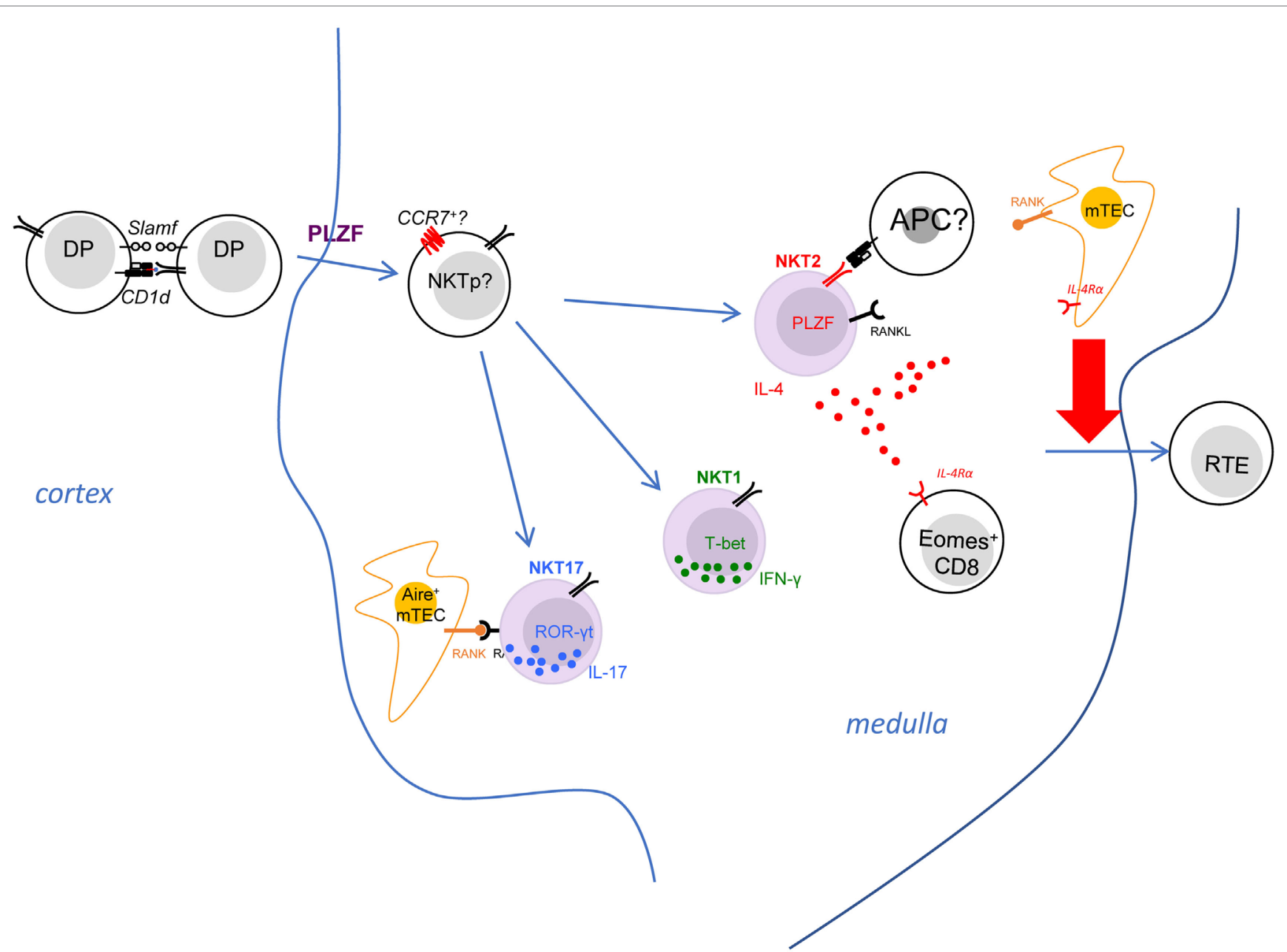

FIGURE 2 | The invariant natural killer T (iNKT) effector subsets modulate immune homeostasis in the thymic medulla. The iNKT effector subsets predominantly reside in the thymic medullary area. Both NKT2 and NKT17 cells express RANK ligand, which interacts with RANK on medullary thymic epithelial (mTEC) to induce Aire expression. NKT2 cells also produce IL-4 at steady state, which has a striking effect on CD $8^{+}$single positive thymocytes - causing them to upregulate Eomes and adopt memory-like phenotype and function. The iNKT-derived type 2 cytokines, IL-4 and IL-13, also influence mTEC to promote emigration of mature thymocytes, through and as-yet undefined mechanism. The activation requirements for NKT2 cells are poorly defined, although they do need T cell receptor stimulation to produce IL-4 in the medulla.

disorganization of the thymic medulla was observed in mice deficient of IL- $4 \mathrm{R} \alpha$, that the medulla contained some epithelial-free areas revealed by the ERTR 5 staining (90). It was speculated that IL-4/13 signaling in mTEC might promote the egress of mature $\mathrm{T}$ cells from thymus, though the specific mechanism remains to be uncovered (90). While the $S 1 \mathrm{p}-\mathrm{S} 1 \mathrm{p} 1$ axis remains intact in the IL-4R $\alpha^{-/-}$mice (90), it is possible that the IL-4/13 produced by NKT2 cells serve as a novel regulator of thymic emigration of T cells.

\section{Periphery}

In the periphery, iNKT cells are critical for restoring homeostasis under stressed conditions. The regulatory role of iNKT cells has been implicated in the type 1 diabetes, where iNKT cells are less frequent and biased toward Th1 cytokine production in diabetic siblings than in their non-diabetic siblings (95). The protective role of iNKT cells has been shown in the mouse model for type 1 diabetes [non-obese diabetes (NOD) mouse], as CD1d ${ }^{-1-}$ NOD mice, lacking iNKT cells, have a higher risk and earlier onsets of diabetes compared to $\mathrm{CD} 1 \mathrm{~d}^{+/+}$counterparts (96). Such protection is dependent on the IL- 4 production by iNKT cells $(97,98)$, and activation of iNKT cells to produce IL- 4 by cognate lipid antigen $\alpha$-Galcer prevents diabetes in NOD mice $(99,100)$.

Recent studies highlighted the key role of iNKT cells in regulating the pathogenesis of graft-versus-host disease (GvHD), a severe immunological dysregulation that frequently occurs after allogeneic hematopoietic stem cell transplantation $(101,102)$. Higher frequency of iNKT cells in patients correlated with lower risk of GvHD (102). In murine studies, stimulation with $\alpha$-Galcer or adoptive transfer of iNKT cells confer substantial protection against GvHD $(103,104)$. Furthermore, the iNKT cell-derived IL-4 and following regulatory $\mathrm{T}$ cells expansion seem to be critical for optimal suppression of GvHD (102-104). These data 
point iNKT cells as promising therapeutic regimen for GvHD patients.

Invariant natural killer $\mathrm{T}$ cells are rare in most peripheral sites (0.1-1\% of lymphocytes), but highly enriched in the liver, representing nearly $30 \%$ of hepatic lymphocytes (23). They are actively involved in restoring tissue homeostasis after sterile liver injury as demonstrated in a recent report (105). Shown by intravital microscopy, iNKT cells randomly patrol the sinusoids within liver in the steady state, while they rapidly move toward the injury site after injury $(105,106)$. Arrested at the injury site due to TCR stimulation and IL-12/18 signals, iNKT cells produce IL-4 to promote a series of events that are vital for optimal tissue repair, including increased proliferation of hepatocytes, the switch of monocyte subtypes from CCR2 $2^{\text {high }} \mathrm{CX} 3 \mathrm{CR} 1^{\text {low }}$ to CCR2 $2^{\text {low }}$ CX3CR $1^{\text {high }}$, as well as reduced collagen deposition (105).

Altogether, these studies demonstrated that iNKT cells are potent regulator in immunity, largely due to their ability to produce abundant cytokines. Most of the studies implicated iNKT cell-derived IL-4 as the critical factor in restoring tissue homeostasis. Therefore, to unleash the therapeutic potential of iNKT cells, it will be important to have better understanding of the underlying mechanisms, especially the relevant APCs and the precise stimulatory lipid antigens that activate iNKT cells to produce IL-4.

\section{Role of Other iNKT Subsets}

Invariant natural killer $\mathrm{T}$ cells also have strong potential to produce other cytokines (IFN $\gamma$ by NKT1 and IL-17 by NKT17). However, the role of these subsets and cytokines on tissue homeostasis has not been deeply explored, although it should be noted that NKT17 are abundant in the lung. iNKT cells also express a variety of other stimulatory or inhibitory molecules; therefore, they might influence immune homeostasis through direct cell contact. One of the molecules expressed by iNKT cells is RANK ligand (RANKL) (24). Signals through tumor necrosis factor family receptors (TNFRSF) RANK promotes Aire expression in mTEC (107). While iNKT cells express RANKL, and Aire ${ }^{+}$ mTECs were significantly reduced in $\mathrm{CD}^{-/-}$mice (24). It strongly suggests that iNKT cells could regulate the development of mTEC through direct cross-talk to induce RANK signals. Further RNA-Seq analysis demonstrates that only NKT2 and NKT17 cells highly express RANKL (28), suggesting that iNKT subsets may have unique effects in modulating tissue homeostasis in the thymus (Figure 2).

\section{THE PARALLELS IN DEVELOPMENT OF INKT CELLS AND MUCOSAL- ASSOCIATED INVARIANT T (MAIT) CELLS}

The MAIT cells are another specialized lineage of innate-like $\mathrm{T}$ cells, expressing a semi-invariant TCR, that V $\alpha 7.2-\mathrm{J} \alpha 33$ chain predominantly paired with $\mathrm{V} \beta 2$ or $\mathrm{V} \beta 13$ in human and $\mathrm{V} \alpha 19-\mathrm{J} \alpha 33$ chain predominantly paired with a $\mathrm{V} \beta 6$ or $\mathrm{V} \beta 8$ in mice (108). They are remarkably abundant in human tissues, making of $1-10 \%$ of $\mathrm{T}$ cells in peripheral blood, nearly $10 \%$ of $\mathrm{T}$ cells in intestine and up to $40 \%$ of $\mathrm{T}$ cells in liver $(109,110)$. Therefore, MAIT cells have attracted great interest in terms of elucidating their development and function. Recently, with the discovery of the vitamin $B$ metabolites as cognate antigens and successful manufacturing of MR-1 tetramer to accurately detect MAIT cells in mice and human $(111,112)$, we have gained a more clear understanding of their development and homeostasis. Surprisingly, the thymic development of MAIT cells parallels many aspects of iNKT cells (Figure 3).

Mucosal-associated invariant $\mathrm{T}$ cells originate in the thymus where their selection depends on the interaction with the MR-1 expressing DP thymocytes (113). Positively selected immature MAIT cells are $\mathrm{CD} 24^{+} \mathrm{CD} 44^{-}$, which give rise to the CD24 $\mathrm{CD}_{4} 4^{+}$mature MAIT cells (70). These $\mathrm{CD} 44^{+}$MAIT cells are comprised of at least two distinct subsets, T-bet ${ }^{+}$MAIT cells and ROR- $\gamma \mathrm{t}^{+}$MAIT cells reminiscences the NKT1 and NKT17 cells. Moreover, like iNKT cells, MAIT cells express PLZF and depends on PLZF for their differentiation, as CD44+ MAIT cells were absent in PLZF-null mice (70). Furthermore, microRNA plays indispensable role in the development of both MAIT cells and iNKT cells, the expansion and differentiation of MAIT cells beyond the $\mathrm{CD} 24^{+}$stage were severely impaired in Droshadeficient mice (70). With the notion that MAIT cells development might parallel the development of iNKT cells, it is reasonable to reference what we learned from iNKT cells to facilitate and advance our understanding of MAIT cells. Many tools designed and hypotheses raised for research of iNKT cells could be applied to that of MAIT cells. Using CD24 and CD44 to distinguish immature and mature MAIT cells, as well as examine expression and dependency of PLZF in MAIT cells are both good examples of that. Taken one step further, more questions could be asked: (1) whether MAIT cells receive strong TCR signal like iNKT cells during selection; (2) whether the two MAIT cell effector subsets require differentiation cues similar to those for NKT1 and NKT17 cells; (3) whether thymic MAIT effector cells predominantly reside in medulla; (4) and PLZF induce tissue residency program in iNKT cells-is it the same in MAIT cells?

\section{MORE INKT SUBSETS: NKT10, NKT $_{\text {FH, }}$ AND ADIPOSE iNKT}

Beside the three effector subsets in the thymus, additional functional subpopulations of iNKT cells have been described. Follicular helper iNKT cells $\left(\mathrm{NKT}_{\mathrm{FH}}\right)$ were detected after immunization with $\alpha$-GalCer-conjugated proteins or haptens $(114,115) . \mathrm{NKT}_{\mathrm{FH}}$ adopt the phenotype of MHC-II restricted $\mathrm{T}$ follicular helper cells $\left(\mathrm{T}_{\mathrm{FH}}\right)$, expressing a variety of classical $\mathrm{T}_{\mathrm{FH}}$ surface markers and transcription factor, including PD-1, CXCR5, ICOS, and Bcl6 $(114,115) . \mathrm{NKT}_{\mathrm{FH}}$ initiate and localize in germinal centers, provide both cognate and noncognate help to lipid and protein-specific B cells, respectively $(114,115)$. However, $\mathrm{NKT}_{\mathrm{FH}}$-dependent germinal center reactions failed to generate long-lived plasma cells (114). Another specialized subpopulation of iNKT cells emerges after stimulation with $\alpha$ GalCer is the regulatory NKT10 cells, characterized by predominant IL-10 production (33). Unlike T regulatory $\left(\mathrm{T}_{\text {reg }}\right)$ cells, NKT10 don't express Foxp3, rather, they highly express E4BP4, a 


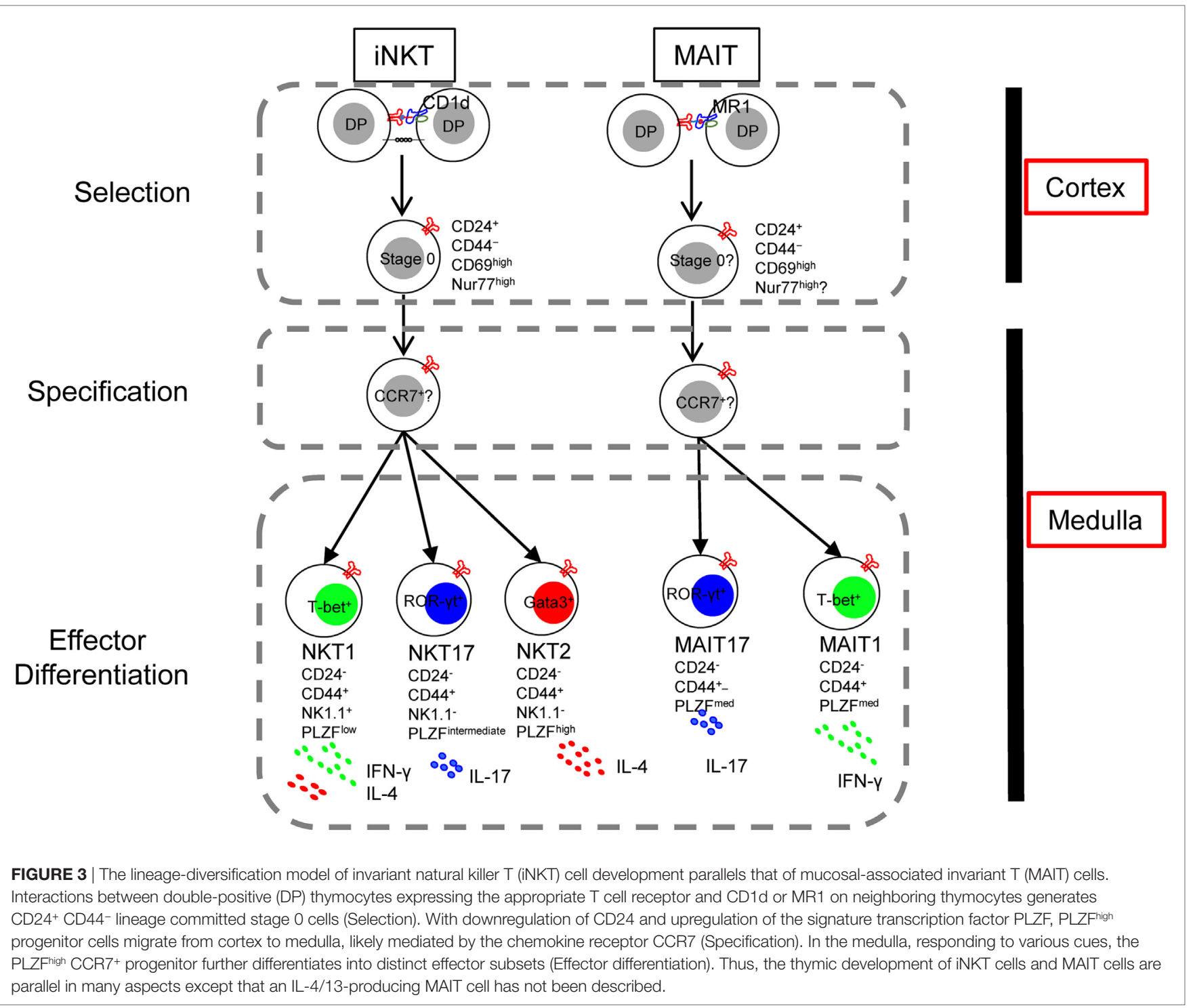

transcription factor regulates IL-10 and IL-13 production in CD4 $\mathrm{T}$ and iNKT cells $(32,33)$.

Adipose iNKT cells have gained focus for their crucial role in modulating $\mathrm{T}_{\text {reg }}$ cells and macrophages, which are correlated with the onset of obesity (116). However, the generation or selection of adipose iNKT cells has been a puzzle. Interestingly, adipose iNKT cells have been found to share phenotype with NKT10 cells, in that they both produce abundant IL-10 and rely on E4BP4 for their regulatory function (34). A recent discovery showed that recognition of CD1d by iNKT TCR controls the development of iNKT cells in the adipose tissue (117). TCR $\alpha$-TCR $\beta$ pairing of iNKT TCR creates a hydrophobic patch, which is critical for maintaining TCR conformation as well as its recognition of CD1d molecule (117). Partial disruption of this patch by substitution of a single amino acid in TCR V $\beta 8.2$ chain (F108Y), while recognition of CD1d preserved, significantly alters the development of iNKT cells, results in an enrichment of iNKT cells in the adipose tissue (117). It is unclear whether this is due to altered selection in the thymus or enhanced proliferation/competitive advantage of adipose iNKT cells on site.

\section{CONCLUDING REMARKS}

T cells play a central role in protecting the body from infectious agents and cancer, but at the same time can cause autoimmune diseases when dysregulated. iNKT cells are a specialized lineage of $\mathrm{T}$ cells that recognize foreign and self-lipids in a manner quite distinct from conventional $\mathrm{T}$ cells. Though iNKT cells are a numerically small population, their striking ability to rapidly produce large amounts of cytokines renders them potent regulators of immunity-implicated in antimicrobial responses, antitumor immunity, and autoimmune and allergic diseases. Despite past progress, a number of questions regarding the development of iNKT cells remain unanswered. First, what is the nature of endogenous lipids recognized by iNKT cells, especially the lipids presented by cortical DP thymocytes that induce positive 
selection of iNKT cells? Second, evidence suggests that NKT2 cells produce large amounts of IL-4 at steady state in the thymus. It is of great interest to understand how this process is regulated. Are antigenic lipids and TCR stimulation required, and if so what is the identity of APCs?

Finally, though iNKT cells are found in most tissues, the frequency of iNKT subsets varies greatly in different organs. For instance, NKT17 are enriched in lung and skin draining LN, while liver iNKT cells are predominantly NKT1. What dictates this striking bias in the distribution of iNKT subsets? How does this differential distribution influence immune responses and/or modulate tissue homeostasis? What is the phenotype of iNKT cells that recently emigrated from thymus to seed in periphery? What are the environmental and cell-intrinsic factors that regulate differentiation or homing of iNKT subsets in various peripheral sites? iNKT stimulatory lipids are well-tolerated in human trials. Through selective activation of different iNKT effector subsets, iNKT cells can modulate immune responses and tissue homeostasis in different fashions. This can only be possible

\section{REFERENCES}

1. Ohteki T, MacDonald HR. Major histocompatibility complex class I related molecules control the development of CD4+8- and CD4-8- subsets of natural killer 1.1+ T cell receptor-alpha/beta+ cells in the liver of mice. J Exp Med (1994) 180(2):699-704. doi:10.1084/jem.180.2.699

2. Makino Y, Kanno R, Ito T, Higashino K, Taniguchi M. Predominant expression of invariant $\mathrm{V}$ alpha 14+ TCR alpha chain in NK1.1+ T cell populations. Int Immunol (1995) 7(7):1157-61. doi:10.1093/intimm/7.7.1157

3. Lantz O, Bendelac A. An invariant $\mathrm{T}$ cell receptor alpha chain is used by a unique subset of major histocompatibility complex class I-specific CD4+ and CD4-8- T cells in mice and humans. J Exp Med (1994) 180(3):1097-106. doi:10.1084/jem.180.3.1097

4. Godfrey DI, Stankovic S, Baxter AG. Raising the NKT cell family. Nat Immunol (2010) 11(3):197-206. doi:10.1038/ni.1841

5. Egawa T, Eberl G, Taniuchi I, Benlagha K, Geissmann F, Hennighausen L, et al. Genetic evidence supporting selection of the Valpha14i NKT cell lineage from double-positive thymocyte precursors. Immunity (2005) 22(6):705-16. doi:10.1016/j.immuni.2005.03.011

6. Benlagha K, Wei DG, Veiga J, Teyton L, Bendelac A. Characterization of the early stages of thymic NKT cell development. J Exp Med (2005) 202(4):485-92. doi:10.1084/jem.20050456

7. Bendelac A. Positive selection of mouse NK1+ T cells by CD1-expressing cortical thymocytes. J Exp Med (1995) 182(6):2091-6. doi:10.1084/jem.182. 6.2091

8. Kovalovsky D, Uche OU, Eladad S, Hobbs RM, Yi W, Alonzo E, et al. The BTB-zinc finger transcriptional regulator PLZF controls the development of invariant natural killer T cell effector functions. Nat Immunol (2008) 9(9):1055-64. doi:10.1038/ni.1641

9. Savage AK, Constantinides MG, Han J, Picard D, Martin E, Li B, et al. The transcription factor PLZF directs the effector program of the NKT cell lineage. Immunity (2008) 29(3):391-403. doi:10.1016/j.immuni.2008.07.011

10. Thomas SY, Scanlon ST, Griewank KG, Constantinides MG, Savage AK, Barr KA, et al. PLZF induces an intravascular surveillance program mediated by long-lived LFA-1-ICAM-1 interactions. J Exp Med (2011) 208(6):1179-88. doi:10.1084/jem.20102630

11. Lee YJ, Holzapfel KL, Zhu J, Jameson SC, Hogquist KA. Steady-state production of IL-4 modulates immunity in mouse strains and is determined by lineage diversity of iNKT cells. Nat Immunol (2013) 14(11):1146-54. doi:10.1038/ni.2731

12. Michel ML, Mendes-da-Cruz D, Keller AC, Lochner M, Schneider E, Dy $\mathrm{M}$, et al. Critical role of ROR-gammat in a new thymic pathway leading to IL-17-producing invariant NKT cell differentiation. Proc Natl Acad Sci U S A (2008) 105(50):19845-50. doi:10.1073/pnas.0806472105 with a better understanding of the developmental steps that drive iNKT cells into functionally distinct subsets.

\section{AUTHOR CONTRIBUTIONS}

HW drafted the manuscript. KH supervised the writing and edited the manuscript.

\section{ACKNOWLEDGMENTS}

We thank Dr. Hristo Georgiev for reading the manuscript, and all present and past members of the Hogquist and Jameson labs for productive discussions and assistance.

\section{FUNDING}

This work was supported by NIH grant R37 AI39560 (KH) and UMN doctoral dissertation fellowship (HW).

13. Watarai H, Sekine-Kondo E, Shigeura T, Motomura Y, Yasuda T, Satoh R, et al. Development and function of invariant natural killer T cells producing T(h)2- and T(h)17-cytokines. PLoS Biol (2012) 10(2):e1001255. doi:10.1371/ journal.pbio. 1001255

14. Dashtsoodol N, Shigeura T, Aihara M, Ozawa R, Kojo S, Harada M, et al. Alternative pathway for the development of Valpha14(+) NKT cells directly from CD4(-)CD8(-) thymocytes that bypasses the CD4(+)CD8(+) stage. Nat Immunol (2017) 18(3):274-82. doi:10.1038/ni.3668

15. Bezbradica JS, Hill T, Stanic AK, Van Kaer L, Joyce S. Commitment toward the natural $\mathrm{T}$ (iNKT) cell lineage occurs at the CD4+8+ stage of thymic ontogeny. Proc Natl Acad Sci U S A (2005) 102(14):5114-9. doi:10.1073/pnas. 0408449102

16. D'Cruz LM, Knell J, Fujimoto JK, Goldrath AW. An essential role for the transcription factor HEB in thymocyte survival, Tcra rearrangement and the development of natural killer T cells. Nat Immunol (2010) 11(3):240-9. doi:10.1038/ ni. 1845

17. Dose M, Sleckman BP, Han J, Bredemeyer AL, Bendelac A, Gounari F. Intrathymic proliferation wave essential for Valpha14+ natural killer T cell development depends on c-Myc. Proc Natl Acad Sci U S A (2009) 106(21): 8641-6. doi:10.1073/pnas.0812255106

18. Mycko MP, Ferrero I, Wilson A, Jiang W, Bianchi T, Trumpp A, et al. Selective requirement for c-Myc at an early stage of V(alpha)14i NKT cell development. J Immunol (2009) 182(8):4641-8. doi:10.4049/jimmunol. 0803394

19. Hu T, Simmons A, Yuan J, Bender TP, Alberola-Ila J. The transcription factor c-Myb primes CD4+CD8+ immature thymocytes for selection into the iNKT lineage. Nat Immunol (2010) 11(5):435-41. doi:10.1038/ni.1865

20. Moran AE, Holzapfel KL, Xing Y, Cunningham NR, Maltzman JS, Punt J, et al. T cell receptor signal strength in Treg and iNKT cell development demonstrated by a novel fluorescent reporter mouse. J Exp Med (2011) 208(6):1279-89. doi:10.1084/jem.20110308

21. Griewank K, Borowski C, Rietdijk S, Wang N, Julien A, Wei DG, et al. Homotypic interactions mediated by Slamf1 and Slamf6 receptors control NKT cell lineage development. Immunity (2007) 27(5):751-62. doi:10.1016/j. immuni.2007.08.020

22. Bendelac A, Savage PB, Teyton L. The biology of NKT cells. Annu Rev Immunol (2007) 25:297-336. doi:10.1146/annurev.immunol.25.022106.141711

23. Lee YJ, Wang H, Starrett GJ, Phuong V, Jameson SC, Hogquist KA. Tissuespecific distribution of iNKT cells impacts their cytokine response. Immunity (2015) 43(3):566-78. doi:10.1016/j.immuni.2015.06.025

24. White AJ, Jenkinson WE, Cowan JE, Parnell SM, Bacon A, Jones ND, et al. An essential role for medullary thymic epithelial cells during the intrathymic development of invariant NKT cells. J Immunol (2014) 192(6):2659-66. doi:10.4049/jimmunol.1303057 
25. Kozai M, Kubo Y, Katakai T, Kondo H, Kiyonari H, Schaeuble K, et al. Essential role of CCL21 in establishment of central self-tolerance in T cells. J Exp Med (2017) 214(7):1925-35. doi:10.1084/jem.20161864

26. Cowan JE, McCarthy NI, Parnell SM, White AJ, Bacon A, Serge A, et al. Differential requirement for CCR4 and CCR7 during the development of innate and adaptive alphabetaT cells in the adult thymus. J Immunol (2014) 193(3):1204-12. doi:10.4049/jimmunol.1400993

27. Engel I, Seumois G, Chavez L, Samaniego-Castruita D, White B, Chawla A, et al. Innate-like functions of natural killer T cell subsets result from highly divergent gene programs. Nat Immunol (2016) 17(6):728-39. doi:10.1038/ ni.3437

28. Lee YJ, Starrett GJ, Lee ST, Yang R, Henzler CM, Jameson SC, et al. Lineagespecific effector signatures of invariant NKT cells are shared amongst gammadelta T, innate lymphoid, and Th cells. J Immunol (2016) 197(4):1460-70. doi:10.4049/jimmunol.1600643

29. Zhu J, Yamane H, Paul WE. Differentiation of effector CD4 T cell populations $\left(^{*}\right)$. Апnu Rev Immunol (2010) 28:445-89. doi:10.1146/annurevimmunol-030409-101212

30. Gordy LE, Bezbradica JS, Flyak AI, Spencer CT, Dunkle A, Sun J, et al. IL-15 regulates homeostasis and terminal maturation of NKT cells. J Immunol (2011) 187(12):6335-45. doi:10.4049/jimmunol.1003965

31. Havenar-Daughton C, Li S, Benlagha K, Marie JC. Development and function of murine RORgammat+ iNKT cells are under TGF-beta signaling control. Blood (2012) 119(15):3486-94. doi:10.1182/blood-2012-01-401604

32. Motomura Y, Kitamura H, Hijikata A, Matsunaga Y, Matsumoto K, Inoue H, et al. The transcription factor E4BP4 regulates the production of IL-10 and IL-13 in CD4+ T cells. Nat Immunol (2011) 12(5):450-9. doi:10.1038/ni.2020

33. Sag D, Krause P, Hedrick CC, Kronenberg M, Wingender G. IL-10-producing NKT10 cells are a distinct regulatory invariant NKT cell subset. J Clin Invest (2014) 124(9):3725-40. doi:10.1172/JCI72308

34. Lynch L, Michelet X, Zhang S, Brennan PJ, Moseman A, Lester C, et al. Regulatory iNKT cells lack expression of the transcription factor PLZF and control the homeostasis of $\mathrm{T}(\mathrm{reg})$ cells and macrophages in adipose tissue. Nat Immunol (2015) 16(1):85-95. doi:10.1038/ni.3047

35. von Moltke J, Ji M, Liang HE, Locksley RM. Tuft-cell-derived IL-25 regulates an intestinal ILC2-epithelial response circuit. Nature (2016) 529(7585):221-5. doi:10.1038/nature16161

36. Seiler MP, Mathew R, Liszewski MK, Spooner CJ, Barr K, Meng F, et al. Elevated and sustained expression of the transcription factors Egr1 and Egr2 controls NKT lineage differentiation in response to TCR signaling. Nat Immunol (2012) 13(3):264-71. doi:10.1038/ni.2230

37. O'Hagan KL, Zhao J, Pryshchep O, Wang CR, Phee H. Pak2 controls acquisition of NKT cell fate by regulating expression of the transcription factors PLZF and Egr2. J Immunol (2015) 195(11):5272-84. doi:10.4049/ jimmunol.1501367

38. Carlson CM, Endrizzi BT, Wu J, Ding X, Weinreich MA, Walsh ER, et al. Kruppel-like factor 2 regulates thymocyte and T-cell migration. Nature (2006) 442(7100):299-302. doi:10.1038/nature04882

39. Weinreich MA, Takada K, Skon C, Reiner SL, Jameson SC, Hogquist KA. KLF2 transcription-factor deficiency in $\mathrm{T}$ cells results in unrestrained cytokine production and upregulation of bystander chemokine receptors. Immunity (2009) 31(1):122-30. doi:10.1016/j.immuni.2009.05.011

40. Weinreich MA, Odumade OA, Jameson SC, Hogquist KA. T cells expressing the transcription factor PLZF regulate the development of memory-like CD8+ T cells. Nat Immunol (2010) 11(8):709-16. doi:10.1038/ni.1898

41. Lai D, Zhu J, Wang T, Hu-Li J, Terabe M, Berzofsky JA, et al. KLF13 sustains thymic memory-like CD8(+) T cells in BALB/c mice by regulating IL-4generating invariant natural killer T cells. J Exp Med (2011) 208(5):1093-103. doi:10.1084/jem.20101527

42. Mackay LK, Minnich M, Kragten NA, Liao Y, Nota B, Seillet C, et al. Hobit and Blimp1 instruct a universal transcriptional program of tissue residency in lymphocytes. Science (2016) 352(6284):459-63. doi:10.1126/science.aad2035

43. van Gisbergen KP, Kragten NA, Hertoghs KM, Wensveen FM, Jonjic S, Hamann J, et al. Mouse Hobit is a homolog of the transcriptional repressor Blimp-1 that regulates NKT cell effector differentiation. Nat Immunol (2012) 13(9):864-71. doi:10.1038/ni.2393

44. Steinke FC, Xue HH. From inception to output, Tcf1 and Lef1 safeguard development of $\mathrm{T}$ cells and innate immune cells. Immunol Res (2014) 59(1-3):45-55. doi:10.1007/s12026-014-8545-9
45. Berga-Bolaños R, Zhu WS, Steinke FC, Xue HH, Sen JM. Cell-autonomous requirement for TCF1 and LEF1 in the development of Natural Killer T cells. Mol Immunol (2015) 68(2 Pt B):484-9. doi:10.1016/j.molimm.2015.09.017

46. Carr T, Krishnamoorthy V, Yu S, Xue HH, Kee BL, Verykokakis M. The transcription factor lymphoid enhancer factor 1 controls invariant natural killer T cell expansion and Th2-type effector differentiation. J Exp Med (2015) 212(5):793-807. doi:10.1084/jem.20141849

47. Tahiliani M, Koh KP, Shen Y, Pastor WA, Bandukwala H, Brudno Y, et al. Conversion of 5-methylcytosine to 5-hydroxymethylcytosine in mammalian DNA by MLL partner TET1. Science (2009) 324(5929):930-5. doi:10.1126/ science. 1170116

48. Ito S, Shen L, Dai Q, Wu SC, Collins LB, Swenberg JA, et al. Tet proteins can convert 5-methylcytosine to 5-formylcytosine and 5-carboxylcytosine. Science (2011) 333(6047):1300-3. doi:10.1126/science.1210597

49. He YF, Li BZ, Li Z, Liu P, Wang Y, Tang Q, et al. Tet-mediated formation of 5-carboxylcytosine and its excision by TDG in mammalian DNA. Science (2011) 333(6047):1303-7. doi:10.1126/science.1210944

50. Tsagaratou A, González-Avalos E, Rautio S, Scott-Browne JP, Togher S, Pastor WA, et al. TET proteins regulate the lineage specification and TCRmediated expansion of iNKT cells. Nat Immunol (2017) 18(1):45-53. doi:10.1038/ni.3630

51. Pereira RM, Martinez GJ, Engel I, Cruz-Guilloty F, Barboza BA, Tsagaratou A, et al. Jarid2 is induced by TCR signalling and controls iNKT cell maturation. Nat Commun (2014) 5:4540. doi:10.1038/ncomms5540

52. Thapa P, Das J, McWilliams D, Shapiro M, Sundsbak R, Nelson-Holte M, et al. The transcriptional repressor NKAP is required for the development of iNKT cells. Nat Commun (2013) 4:1582. doi:10.1038/ncomms2580

53. Thapa P, Romero Arocha S, Chung JY, Sant'Angelo DB, Shapiro VS. Histone deacetylase 3 is required for iNKT cell development. Sci Rep (2017) 7(1):5784. doi:10.1038/s41598-017-06102-5

54. Beyaz S, Kim JH, Pinello L, Xifaras ME, Hu Y, Huang J, et al. The histone demethylase UTX regulates the lineage-specific epigenetic program of invariant natural killer T cells. Nat Immunol (2017) 18(2):184-95. doi:10.1038/ni.3644

55. Bartel DP. MicroRNAs: genomics, biogenesis, mechanism, and function. Cell (2004) 116(2):281-97. doi:10.1016/S0092-8674(04)00045-5

56. Fedeli M, Napolitano A, Wong MP, Marcais A, de Lalla C, Colucci F, et al. Dicer-dependent microRNA pathway controls invariant NKT cell development. J Immunol (2009) 183(4):2506-12. doi:10.4049/jimmunol.0901361

57. Li QJ, Chau J, Ebert PJ, Sylvester G, Min H, Liu G, et al. miR-181a is an intrinsic modulator of T cell sensitivity and selection. Cell (2007) 129(1): 147-61. doi:10.1016/j.cell.2007.03.008

58. Ziętara N, Łyszkiewicz M, Witzlau K, Naumann R, Hurwitz R, Langemeier J, et al. Critical role for miR-181a/b-1 in agonist selection of invariant natural killer T cells. Proc Natl Acad Sci U S A (2013) 110(18):7407-12. doi:10.1073/ pnas. 1221984110

59. Fedeli M, Riba M, Garcia Manteiga JM, Tian L, Viganò V, Rossetti G, et al. miR-17 approximately 92 family clusters control iNKT cell ontogenesis via modulation of TGF-beta signaling. Proc Natl Acad Sci U S A (2016) 113(51):E8286-95. doi:10.1073/pnas.1612024114

60. Yuan J, Nguyen CK, Liu X, Kanellopoulou C, Muljo SA. Lin28b reprograms adult bone marrow hematopoietic progenitors to mediate fetal-like lymphopoiesis. Science (2012) 335(6073):1195-200. doi:10.1126/science.1216557

61. Pobezinsky LA, Etzensperger R, Jeurling S, Alag A, Kadakia T, McCaughtry TM, et al. Let-7 microRNAs target the lineage-specific transcription factor PLZF to regulate terminal NKT cell differentiation and effector function. Nat Immunol (2015) 16(5):517-24. doi:10.1038/ni.3146

62. Bezman NA, Chakraborty T, Bender T, Lanier LL. miR-150 regulates the development of NK and iNKT cells. J Exp Med (2011) 208(13):2717-31. doi:10.1084/jem.20111386

63. Zheng Q, Zhou L, Mi QS. MicroRNA miR-150 is involved in Valpha14 invariant NKT cell development and function. J Immunol (2012) 188(5): 2118-26. doi:10.4049/jimmunol.1103342

64. Mao AP, Ishizuka IE, Kasal DN, Mandal M, Bendelac A. A shared Runx1bound Zbtb16 enhancer directs innate and innate-like lymphoid lineage development.NatCommun (2017) 8(1):863. doi:10.1038/s41467-017-00882-0

65. Mao AP, Constantinides MG, Mathew R, Zuo Z, Chen X, Weirauch MT, et al. Multiple layers of transcriptional regulation by PLZF in NKT-cell development. Proc Natl Acad Sci U S A (2016) 113(27):7602-7. doi:10.1073/ pnas. 1601504113 
66. Mathew R, Seiler MP, Scanlon ST, Mao AP, Constantinides MG, BertozziVilla C, et al. BTB-ZF factors recruit the E3 ligase cullin 3 to regulate lymphoid effector programs. Nature (2012) 491(7425):618-21. doi:10.1038/nature11548

67. Vasanthakumar A, Xu D, Lun AT, Kueh AJ, van Gisbergen KP, Iannarella N, et al. A non-canonical function of Ezh2 preserves immune homeostasis. EMBO Rep (2017) 18(4):619-31. doi:10.15252/embr.201643237

68. Pellicci DG, Hammond KJ, Uldrich AP, Baxter AG, Smyth MJ, Godfrey DI. A natural killer T (NKT) cell developmental pathway iInvolving a thymusdependent NK1.1(-)CD4(+) CD1d-dependent precursor stage. J Exp Med (2002) 195(7):835-44. doi:10.1084/jem.20011544

69. Olszak T, An D, Zeissig S, Vera MP, Richter J, Franke A, et al. Microbial exposure during early life has persistent effects on natural killer T cell function. Science (2012) 336(6080):489-93. doi:10.1126/science.1219328

70. Koay HF, Gherardin NA, Enders A, Loh L, Mackay LK, Almeida CF, et al. A three-stage intrathymic development pathway for the mucosal-associated invariant T cell lineage. Nat Immunol (2016) 17(11):1300-11. doi:10.1038/ ni. 3565

71. Albu DI, VanValkenburgh J, Morin N, Califano D, Jenkins NA, Copeland NG, et al. Transcription factor Bcl11b controls selection of invariant natural killer T-cells by regulating glycolipid presentation in double-positive thymocytes. Proc Natl Acad Sci U S A (2011) 108(15):6211-6. doi:10.1073/ pnas. 1014304108

72. Jayawardena-Wolf J, Benlagha K, Chiu YH, Mehr R, Bendelac A. CD1d endosomal trafficking is independently regulated by an intrinsic CD1d-encoded tyrosine motif and by the invariant chain. Immunity (2001) 15(6):897-908. doi:10.1016/S1074-7613(01)00240-0

73. Chiu YH, Park SH, Benlagha K, Forestier C, Jayawardena-Wolf J, Savage PB, et al. Multiple defects in antigen presentation and $\mathrm{T}$ cell development by mice expressing cytoplasmic tail-truncated CD1d. Nat Immunol (2002) 3(1):55-60. doi: $10.1038 / \mathrm{ni} 740$

74. Mori L, Lepore M, De Libero G. The immunology of CD1- and MR1restricted T cells. Annu Rev Immunol (2016) 34:479-510. doi:10.1146/ annurev-immunol-032414-112008

75. Salio M, Silk JD, Jones EY, Cerundolo V. Biology of CD1- and MR1restricted T cells. Annu Rev Immunol (2014) 32:323-66. doi:10.1146/ annurev-immunol-032713-120243

76. Mattner J, Debord KL, Ismail N, Goff RD, Cantu C III, Zhou D, et al. Exogenous and endogenous glycolipid antigens activate NKT cells during microbial infections. Nature (2005) 434(7032):525-9. doi:10.1038/nature03408

77. Porubsky S, Speak AO, Luckow B, Cerundolo V, Platt FM, Gröne HJ. Normal development and function of invariant natural killer $\mathrm{T}$ cells in mice with isoglobotrihexosylceramide (iGb3) deficiency. Proc Natl Acad Sci U S A (2007) 104(14):5977-82. doi:10.1073/pnas.0611139104

78. Popovic ZV, Rabionet M, Jennemann R, Krunic D, Sandhoff R, Gröne HJ, et al. Glucosylceramide synthase is involved in development of invariant natural killer T cells. Front Immunol (2017) 8:848. doi:10.3389/fimmu.2017.00848

79. Kain L, Webb B, Anderson BL, Deng S, Holt M, Costanzo A, et al. The identification of the endogenous ligands of natural killer $\mathrm{T}$ cells reveals the presence of mammalian alpha-linked glycosylceramides. Immunity (2014) 41(4):543-54. doi:10.1016/j.immuni.2014.08.017

80. Lairson LL, Henrissat B, Davies GJ, Withers SG. Glycosyltransferases: structures, functions, and mechanisms. Annu Rev Biochem (2008) 77:521-55. doi:10.1146/annurev.biochem.76.061005.092322

81. Brennan PJ, Tatituri RV, Brigl M, Kim EY, Tuli A, Sanderson JP, et al. Invariant natural killer $\mathrm{T}$ cells recognize lipid self antigen induced by microbial danger signals. Nat Immunol (2011) 12(12):1202-11. doi:10.1038/ni.2143

82. Brennan PJ, Tatituri RV, Heiss C, Watts GF, Hsu FF, Veerapen N, et al. Activation of iNKT cells by a distinct constituent of the endogenous glucosylceramide fraction. Proc Natl Acad Sci U S A (2014) 111(37):13433-8. doi:10.1073/pnas.1415357111

83. Kain L, Costanzo A, Webb B, Holt M, Bendelac A, Savage PB, et al. Endogenous ligands of natural killer $\mathrm{T}$ cells are alpha-linked glycosylceramides. $\mathrm{Mol}$ Immunol (2015) 68(2 Pt A):94-7. doi:10.1016/j.molimm.2015.06.009

84. Facciotti F, Ramanjaneyulu GS, Lepore M, Sansano S, Cavallari M, Kistowska $\mathrm{M}$, et al. Peroxisome-derived lipids are self antigens that stimulate invariant natural killer T cells in the thymus. Nat Immunol (2012) 13(5):474-80. doi:10.1038/ni.2245

85. Paduraru C, Bezbradica JS, Kunte A, Kelly R, Shayman JA, Veerapen N, et al. Role for lysosomal phospholipase A2 in iNKT cell-mediated CD1d recognition. Proc Natl Acad Sci U S A (2013) 110(13):5097-102. doi:10.1073/ pnas. 1302923110

86. McNab FW, Berzins SP, Pellicci DG, Kyparissoudis K, Field K, Smyth MJ, et al. The influence of CD1d in postselection NKT cell maturation and homeostasis. J Immunol (2005) 175(6):3762-8. doi:10.4049/jimmunol.175. 6.3762

87. Clancy-Thompson E, Chen GZ, Tyler PM, Servos MM, Barisa M, Brennan PJ, et al. Monoclonal invariant NKT (iNKT) cell mice reveal a role for both tissue of origin and the TCR in development of iNKT functional subsets. J Immunol (2017) 199(1):159-71. doi:10.4049/jimmunol.1700214

88. Schümann J, Mycko MP, Dellabona P, Casorati G, MacDonald HR. Cutting edge: influence of the TCR Vbeta domain on the selection of semiinvariant NKT cells by endogenous ligands. J Immunol (2006) 176(4):2064-8. doi:10.4049/jimmunol.176.4.2064

89. Cruz Tleugabulova M, Escalante NK, Deng S, Fieve S, Ereño-Orbea J, Savage PB, et al. Discrete TCR binding kinetics control invariant NKT cell selection and central priming. J Immunol (2016) 197(10):3959-69. doi:10.4049/ jimmunol.1601382

90. White AJ, Baik S, Parnell SM, Holland AM, Brombacher F, Jenkinson WE, et al. A type 2 cytokine axis for thymus emigration. J Exp Med (2017) 214(8): 2205-16. doi:10.1084/jem.20170271

91. Jameson SC, Lee YJ, Hogquist KA. Innate memory T cells. Adv Immuno (2015) 126:173-213. doi:10.1016/bs.ai.2014.12.001

92. Renkema KR, Lee JY, Lee YJ, Hamilton SE, Hogquist KA, Jameson SC. IL-4 sensitivity shapes the peripheral CD8+ T cell pool and response to infection. J Exp Med (2016) 213(7):1319-29. doi:10.1084/jem.20151359

93. Lee A, Park SP, Park CH, Kang BH, Park SH, Ha SJ, et al. IL-4 induced innate CD8+ T cells control persistent viral infection. PLoS Pathog (2015) 11(10):e1005193. doi:10.1371/journal.ppat.1005193

94. White JT, Cross EW, Kedl RM. Antigen-inexperienced memory CD8(+) T cells: where they come from and why we need them. Nat Rev Immunol (2017) 17(6):391-400. doi:10.1038/nri.2017.34

95. Wilson SB, Kent SC, Patton KT, Orban T, Jackson RA, Exley M, et al. Extreme Th1 bias of invariant Valpha24JalphaQ T cells in type 1 diabetes. Nature (1998) 391(6663):177-81. doi:10.1038/34419

96. Wang B, Geng YB, Wang CR. CD1-restricted NK T cells protect nonobese diabetic mice from developing diabetes. J Exp Med (2001) 194(3):313-20. doi:10.1084/jem.194.3.313

97. Mi QS, Ly D, Zucker P, McGarry M, Delovitch TL. Interleukin-4 but not interleukin-10 protects against spontaneous and recurrent type 1 diabetes by activated CD1d-restricted invariant natural killer T-cells. Diabetes (2004) 53(5):1303-10. doi:10.2337/diabetes.53.5.1303

98. Kent SC, Chen Y, Clemmings SM, Viglietta V, Kenyon NS, Ricordi C, et al. Loss of IL-4 secretion from human type la diabetic pancreatic draining lymph node NKT cells. J Immunol (2005) 175(7):4458-64. doi:10.4049/jimmunol. 175.7.4458

99. Hong S, Wilson MT, Serizawa I, Wu L, Singh N, Naidenko OV, et al. The natural killer T-cell ligand alpha-galactosylceramide prevents autoimmune diabetes in non-obese diabetic mice. Nat Med (2001) 7(9):1052-6. doi:10.1038/ nm0901-1052

100. Sharif S, Arreaza GA, Zucker P, Mi QS, Sondhi J, Naidenko OV, et al. Activation of natural killer $\mathrm{T}$ cells by alpha-galactosylceramide treatment prevents the onset and recurrence of autoimmune Type 1 diabetes. Nat Med (2001) 7(9):1057-62. doi:10.1038/nm0901-1057

101. Blazar BR, Murphy WJ, Abedi M. Advances in graft-versus-host disease biology and therapy. Nat Rev Immunol (2012) 12(6):443-58. doi:10.1038/ nri3212

102. Mavers M, Maas-Bauer K, Negrin RS. Invariant natural killer T cells as suppressors of graft-versus-host disease in allogeneic hematopoietic stem cell transplantation. Front Immunol (2017) 8:900. doi:10.3389/fimmu.2017 00900

103. Hashimoto D, Asakura S, Miyake S, Yamamura T, Van Kaer L, Liu C, et al. Stimulation of host NKT cells by synthetic glycolipid regulates acute graftversus-host disease by inducing Th2 polarization of donor T cells. J Immunol (2005) 174(1):551-6. doi:10.4049/jimmunol.174.1.551

104. Du J, Paz K, Thangavelu G, Schneidawind D, Baker J, Flynn R, et al. Invariant natural killer T cells ameliorate murine chronic GVHD by expanding donor regulatory T cells. Blood (2017) 129(23):3121-5. doi:10.1182/blood-2016$11-752444$ 
105. Liew PX, Lee WY, Kubes P. iNKT cells orchestrate a switch from inflammation to resolution of sterile liver injury. Immunity (2017) 47(4):752-65.e5. doi:10.1016/j.immuni.2017.09.016

106. Geissmann F, Cameron TO, Sidobre S, Manlongat N, Kronenberg M, Briskin MJ, et al. Intravascular immune surveillance by CXCR6+ NKT cells patrolling liver sinusoids. PLoS Biol (2005) 3(4):e113. doi:10.1371/journal. pbio.0030113

107. Akiyama T, Shimo Y, Yanai H, Qin J, Ohshima D, Maruyama Y, et al. The tumor necrosis factor family receptors RANK and CD40 cooperatively establish the thymic medullary microenvironment and self-tolerance. Immunity (2008) 29(3):423-37. doi:10.1016/j.immuni.2008.06.015

108. Treiner E, Lantz O. CD1d- and MR1-restricted invariant T cells: of mice and men. Curr Opin Immunol (2006) 18(5):519-26. doi:10.1016/j.coi.2006.07.001

109. Dusseaux M, Martin E, Serriari N, Péguillet I, Premel V, Louis D, et al. Human MAIT cells are xenobiotic-resistant, tissue-targeted, CD161hi IL-17-secreting T cells. Blood (2011) 117(4):1250-9. doi:10.1182/blood-2010-08-303339

110. Martin E, Treiner E, Duban L, Guerri L, Laude H, Toly C, et al. Stepwise development of MAIT cells in mouse and human. PLoS Biol (2009) 7(3):e54. doi:10.1371/journal.pbio.1000054

111. Kjer-Nielsen L, Patel O, Corbett AJ, Le Nours J, Meehan B, Liu L, et al. MR1 presents microbial vitamin B metabolites to MAIT cells. Nature (2012) 491(7426):717-23. doi:10.1038/nature11605

112. Reantragoon R, Corbett AJ, Sakala IG, Gherardin NA, Furness JB, Chen Z, et al. Antigen-loaded MR1 tetramers define T cell receptor heterogeneity in mucosal-associated invariant T cells. J Exp Med (2013) 210(11):2305-20. doi:10.1084/jem.20130958

113. Seach N, Guerri L, Le Bourhis L, Mburu Y, Cui Y, Bessoles S, et al. Doublepositive thymocytes select mucosal-associated invariant T cells. J Immunol (2013) 191(12):6002-9. doi:10.4049/jimmunol.1301212
114. Chang PP, Barral P, Fitch J, Pratama A, Ma CS, Kallies A, et al. Identification of Bcl-6-dependent follicular helper NKT cells that provide cognate help for B cell responses. Nat Immunol (2011) 13(1):35-43. doi:10.1038/ni.2166

115. King IL, Fortier A, Tighe M, Dibble J, Watts GF, Veerapen N, et al. Invariant natural killer $\mathrm{T}$ cells direct $\mathrm{B}$ cell responses to cognate lipid antigen in an IL-21-dependent manner. Nat Immunol (2011) 13(1):44-50. doi:10.1038/ ni. 2172

116. Lynch L, Nowak M, Varghese B, Clark J, Hogan AE, Toxavidis V, et al. Adipose tissue invariant NKT cells protect against diet-induced obesity and metabolic disorder through regulatory cytokine production. Immunity (2012) 37(3):574-87. doi:10.1016/j.immuni.2012.06.016

117. Vieth JA, Das J, Ranaivoson FM, Comoletti D, Denzin LK, Sant'Angelo DB. TCRalpha-TCRbeta pairing controls recognition of CD1d and directs the development of adipose NKT cells. Nat Immunol (2017) 18(1):36-44 doi:10.1038/ni.3622

Conflict of Interest Statement: The authors declare that the research was conducted in the absence of any commercial or financial relationships that could be construed as a potential conflict of interest.

The reviewer SJ and handling Editor declared their shared affiliation.

Copyright (C) 2018 Wang and Hogquist. This is an open-access article distributed under the terms of the Creative Commons Attribution License (CC BY). The use, distribution or reproduction in other forums is permitted, provided the original author(s) and the copyright owner are credited and that the original publication in this journal is cited, in accordance with accepted academic practice. No use, distribution or reproduction is permitted which does not comply with these terms. 